\title{
Monika Woźniak*
}

\author{
University of San Jorge, Spain \\ mwozniak@usj.es
}

\section{ESP IN CLIL DEGREE PROGRAMMES}

\section{Abstract}

In view of the growing amount of English used outside language courses, this study seeks to gain insights into how language teachers at university level understand and navigate their changing roles. It examines the place of ESP teaching in a university setting in Spain where almost all language lecturers play a double role: they teach obligatory ESP courses and also support content lecturers in the integration of English into their subjects as CLIL tutors. The results of two openended questionnaires and interviews with ESP lecturers/CLIL tutors show that interdisciplinary teacher cooperation concentrates on raising content teachers' awareness of teaching methodology and language issues in their disciplines, but also benefits the design of ESP courses. Language specialists view their multiple and fluid roles as an opportunity to expand their horizons and welcome the chance to mediate between disciplines and participate in students' academic and disciplinary development not only in ESP courses but also throughout the degree programme. Despite the increasingly blurred dividing line between ESP and CLIL at university level, the two approaches, rather than compete, can complement each other, so to this end, language specialists' effort to find the right balance between language and content knowledge should also be addressed.

\section{Key words}

ESP, CLIL, university, teacher collaboration, disciplinary literacies.

\footnotetext{
* Corresponding address: Monika Woźniak, Campus Universitario Villanueva de Gállego Autov. A23 Zaragoza - Huesca, Km. 510, 50830 Villanueva de Gállego - Zaragoza, Spain.
} 


\section{Sažetak}

S obzirom na sve češću upotrebu engleskog izvan jezičkih kurseva, ovaj rad ima za cilj sticanje uvida u to kako nastavnici jezika na univerzitetskom nivou shvataju svoje izmenjene uloge i kako se u njima snalaze. Istražujemo mesto nastave engleskog jezika nauke i struke u univerzitetskom okruženju u Španiji u kome skoro svi nastavnici jezika imaju dvostruku ulogu: predaju obavezne kurseve engleskog jezika nauke i struke, a služe i kao podrška predmetnim profesorima pri integraciji engleskog u njihove predmete kao tutori u integrisanoj nastavi jezika i stručnog gradiva. Rezultati dva upitnika sa otvorenim odgovorima i intervjua sa predavačima engleskog jezika nauke i struke i tutorima u integrisanoj nastavi jezika i stručnog gradiva pokazuju da je interdisciplinarna saradnja među nastavnicima usmerena ka povećanju svesti predmetnih nastavnika o metodologiji nastave i jezičkim problemima u njihovim disciplinama, ali i da takva saradnja pomaže osmišljavanju kurseva engleskog jezika nauke i struke. Jezički stručnjaci tretiraju svoje višestruke i fluidne uloge kao priliku da prošire vidike i pozdravljaju mogućnost da posreduju između disciplina i učestvuju u akademskom i disciplinarnom razvoju studenata ne samo na kursevima engleskog nauke i struke, već i iz ostalih predmeta. Uprkos sve nejasnijoj liniji razdvajanja između nastave engleskog nauke i struke i integrisane nastave jezika i stručnog gradiva na univerzitetskom nivou, ta dva pristupa su pre komplementarna nego isključiva, te se u tom smislu mora obratiti pažnja na napore jezičkih stručnjaka da pronađu pravu ravnotežu između znanja jezika i znanja stručnog gradiva.

\section{Ključne reči}

engleski jezik nauke i struke, integrisano učenje jezika i stručnog gradiva, univerzitet, saradnja među nastavnicima, disciplinarna pismenost.

\section{INTRODUCTION}

English for Specific Purposes (ESP) is concerned with the teaching and learning of English as a second or foreign language to learn and use it in a particular academic or professional domain. As Paltridge and Starfield (2013: 2) put it, "[a] key feature of an ESP course is that the content and aims of the course are oriented to the specific needs of the learners. ESP courses, then, focus on the language, skills, and genres appropriate to the specific activities the learners need to carry out in English". 
Considering the growing trend in universities across non-English speaking countries for subject specialists to use English to teach academic content, ESP courses taught by language specialists are only one of the environments where students use English within their respective disciplines. The main labels used in reference to the teaching of academic content subjects through the medium of English are EMI (English-medium Instruction) and CLIL (Content and Language Integrated Learning). While EMI primarily means changing the language of instruction and does not aim at enhancing students' language skills (Dearden, 2014), CLIL is a dual-focused educational approach aimed at the concurrent teaching and learning of both academic subject matter and the additional language, although the two elements are not always pursued to the same degree (Coyle, Hood, \& Marsh, 2010). This rapid spread of English outside of standard language courses poses pertinent questions about the role, position, and future of language courses and departments, especially in regard to traditional ESP courses (Dearden, 2014; Räisänen \& Fortanet-Gómez, 2008). However, this new context of learning also creates new opportunities for ESP specialists to redefine traditional disciplinary divisions and promote interaction and collaboration between disciplines to better integrate content and language in ESP courses and better adapt them to students' communicative needs (Arnó-Macià \& Mancho-Barés, 2015). Their expertise in disciplinary language can play a key role in the implementation of effective CLIL in tertiary institutions (Taillefer, 2013).

Since language teachers' perceptions of their roles in the ESP and CLIL models of instruction seem to remain under-researched, the present article is an attempt to examine the implications, tasks, and challenges of ESP teaching by drawing on the example of a single university environment where English is integrated in content subjects and where ESP lecturers play a double role. Apart from teaching ESP subjects, they support content teachers in the process of their CLIL teaching. Conducted from a qualitative perspective, this study analyses their insights and understandings of their role and contribution to CLIL undergraduate degree programmes in which English is integrated in content subjects as an additional language. The paper begins with an overview of ESP teaching and teacher collaboration at tertiary level for academic and disciplinary literacies and a brief description of the setting under investigation. In the following sections, the research questions and methodological underpinnings are described, followed by a discussion of the findings.

\section{ESP SPECIALISTS IN CLIL PROGRAMMES}

Apart from linguistic proficiency, using a foreign language for study or work purposes requires knowledge and understanding of disciplinary and work-related concepts, so openness and engagement with other disciplines, their practices and peculiarities have always been an essential part of ESP (Dudley-Evans \& St John, 
1998). By contrast, the introduction of an additional language into the teaching of content subjects challenges the conventional roles assigned to content and language specialists and the traditional ways of designing and delivering their courses (Airey, 2016; Dafouz, Hüttner, \& Smit, 2016; Skinnari \& Bovellan, 2016; Taillefer, 2013). Although disciplinary language, skills, and genres in English are increasingly present in content subjects, subject experts tend to concentrate on disciplinary concepts, skills, and mind-sets and treat language merely as a tool for content learning and discipline-related tasks and not as an aim that requires explicit attention, language pedagogy, or assessment (Airey, 2016; Jacobs, 2005, 2007; Yang, 2016; Zhang, 2016). Despite the dual focus in CLIL, university curricula and course syllabuses tend to treat language learning as a 'side effect' and do not specify it in study guides and learning outcomes (Airey, 2016; Arnó-Macià \& Mancho-Barés, 2015).

Considering the still limited attention to students' language development in CLIL, it is ESP practitioners who can address, support, and assess it properly and both ESP and CLIL are still compatible (González Ardeo, 2013; Taillefer, 2013). Yang (2016) found that ESP learners have more chances to use English in class than their CLIL peers, whereas CLIL teachers are more positive about their students' language developments than their ESP colleagues, even if they did not assess them formally. Tarnopolsky (2013) maintains that in non-English speaking countries, traditional language-focused ESP courses are even desirable at the beginning of university studies as they gradually introduce students into the peculiarities of disciplinary language and provide assistance with ongoing difficulties with English. A traditional language-focused course is also important for novice students' transition from secondary school because of their lack of knowledge about their discipline and future profession. Tarnopolsky (2013: 9) proposes a sequence of approaches throughout degree programmes which integrate disciplinary language and content in line with students' progressive academic development: "traditional (language-focused) ESP training (a language course), content-based (theme-based) instruction (a language course), sheltered immersion (a course on a non-linguistic discipline), partial immersion (a course on a non-linguistic discipline), and total immersion (a course on a non-linguistic discipline)". Leonardi (2015), in turn, postulates that the differences between ESP and CLIL no longer apply at university level and maintains that despite students' lack of content knowledge, incorporating certain content knowledge in the ESP course will promote active learning and benefit students. She highlights the points of convergence between ESP and CLIL such as student-centred learning, use of authentic materials, communicative teaching, contextualised class activities, taskbased activities, and development of cultural awareness. The right balance between a focus on meaning and form, albeit difficult, can be achieved in cooperation with content subject specialists who can help to select the most important topics, materials, or tasks. 
Given the high level of expertise required to teach at higher education level, teachers cannot traverse each other's territories easily and the two-fold focus of CLIL calls for interdisciplinary collaboration between language and content specialists, though lack of contact between faculties, interdisciplinary tensions, in addition to time and effort required complicate its implementation (Airey, 2016; Arnó-Macià \& Mancho-Barés, 2015; Tudor, 2008; Weinberg \& Symon, 2017). Even if language specialists have expertise in ESP teaching for particular domains, they typically lack advanced knowledge of professional practices and workplace norms to be able to prepare their students for disciplinary practices. Content lecturers, as disciplinary experts, can share their knowledge about social practices of their discourse communities, but they usually lack language teaching training and may not be aware of the role of language in the processes of disciplinary learning and teaching. In non-English speaking countries like Spain, initiatives between content and language teachers are often dictated by the needs of the content teachers in terms of support and guidance on using English in their teaching practice. Rarely having pedagogical training, university teachers of content are not aware of many pedagogical and methodological implications of their teaching, let alone teaching through the medium of a foreign language (Aguilar \& Rodríguez, 2012; FortanetGómez, 2013).

\section{ACADEMIC AND DISCIPLINARY LITERACIES AT UNIVERSITY}

Students need specialised language to engage with disciplinary knowledge as there is a strong link between students' knowledge of the discipline and its discourse (Woodward-Kron, 2008). Disciplinary literacy "emphasizes the unique tools that the experts in a discipline use to participate in the work of that discipline" (Shanahan \& Shanahan, 2008: 8). Masuda (2014) identifies five elements of disciplinary literacy: habits of thinking, texts, reading and writing demands, specific language and vocabulary, and instructional tools. Therefore, learning within a particular discipline also involves linguistic work on how to understand and construct knowledge, communicate within the field of specialisation, and critically evaluate the information available. Language issues are more visible when an additional language comes into play but attention to disciplinary literacies for successful disciplinary communication is also required in native speaker contexts. Academic writing and discourse communities are no longer considered 'monolithic and homogeneous' (Hyland, 2004: x) and home students are also novices to complex academic and disciplinary communities and equally need support when dealing with unfamiliar discourses (Thesen \& van Pletzen, 2006).

The UK model of academic literacies focuses on practices in academic writing rather than texts and genres. This paradigm is based on Lea and Street's (1998, 
2006) notion of "academic literacies" in a three-level framework for educational programmes in writing in higher education. The three levels comprise a skills model, an academic socialisation model, and an academic literacies model (Lea \& Street, 1998: 158-159). The "skills model" focuses on the surface features of texts. It treats literacy components as isolated technical skills which are transferable from one context to another and which are required for a specific course, level of education, or profession. The "academic socialisation model" views skills as inserted in a social or disciplinary context. The emphasis is on identifying existing academic and disciplinary conventions and producing texts for a given discipline, so teachers induct their students into using the identified and relatively stable disciplinary practices, discourses, and genres. This 'stability' makes it 'normative' (Lillis \& Scott, 2007: 9-13). The "academic literacies model" draws on the two previous ones but is the most inclusive. It treats writing as a social practice and views communication practices as complex, dynamic, and epistemologically integral to a given culture. It recognises the complexity of the disciplines and university settings and recognises students' own identities and experiences and alternative ways of meaning making which do not always coincide with their teachers' expectations. Lillis and Scott (2007) highlight that this 'transformative' interest is also indicated by the plural form 'academic literacies', although both the singular and plural forms are used and inspire debate. They use the plural form to mean "a specific epistemological and ideological approach towards academic writing and communication" (2007: 13). In Anglophone higher education, academic literacies is primarily aimed at native students with 'writing deficiencies', while EAP (English for Academic Purposes) is for non-native speakers of English. Wingate and Tribble (2012) combine the shared principles of these two main approaches to academic writing and propose discipline-specific text-based approaches which are also transformative and inclusive. They emphasise that "the more they are linked to the teaching of subject content, the greater is their potential to raise students' awareness of the disciplines' communicative and social practices" (2012: 492). Wingate (2015) frames academic literacy as the ability to communicate competently in a discourse community. With this understanding, academic literacy instruction goes beyond academic writing and approaches language through its social and communicative function. Students' literacy knowledge and practices will be transformed into disciplinary writing practices embedded in the subject and gradually discovered throughout the curriculum. Subject specialists, as insiders into the conventions of the discourse community, are invaluable in this approach as a source of information on the genre's social context.

In non-English speaking countries, the cultural peculiarities of academic disciplines are also noticeable in their treatment of the English language. Kuteeva and Airey (2014) show that different knowledge making practices and educational goals across disciplines are reflected in varied attitudes towards the use of English and relate them to particular disciplinary knowledge structures discussed by 
Bernstein (1999). Under the assumption that the 'product' of university education is a disciplinary literate graduate, Airey (2011, "Disciplinary Literacy", para. 4) defines the term disciplinary literacy as "the ability to appropriately participate in the communicative practices of the discipline". This ability involves semiotic resources for the negotiation, construction, and dissemination of knowledge, which can also involve the use of English. He further illustrates disciplinary literacy goals as a disciplinary literacy triangle comprising three interrelated areas: the academy, the workplace, and society. Although the value of each component will vary between academic disciplines, the three areas are present in all academic disciplines and represent different communicative practices and forms of local and international communication. Disciplinary differences in the attitude towards English demonstrate why general one-size-fits-all university language policies may prove ineffective and that policies regarding the use of English need to be flexible and adjustable to disciplinary goals, discipline-specific genres, and the role of English in disciplinary knowledge creation and communication (Airey, Lauridsen, Räsänen, Salö, \& Schwach, 2017; Kuteeva \& Airey, 2014). Airey et al. (2017) underscore the need to teach and assess disciplinary literacy outcomes in Englishtaught programmes and postulate that in order to achieve it, course syllabuses should incorporate detailed disciplinary language outcomes and skills in English as an integral part of the course.

Airey (2016: 78) lists three approaches to teacher collaboration at tertiary level: EMI (content) supported by EAP classes (language); team teaching with content and language teachers together in the classroom (not tenable for financial reasons); and finally, content teachers responsible for both content and language outcomes but with language teachers to help uncover tacit assumptions about disciplinary discourse. Jacobs (2007) developed a model for collaboration between content and language specialists in the integration of academic literacies into disciplines. This model includes collaborative interactions, nature of relationship, power relationships, and roles and responsibilities within the collaborative team. Next to teachers' active involvement and willingness to change their conceptualisations of academic discourses and traditional teacher roles, Jacobs (2007) also highlights the importance of trust and congruence in the roles of the partners as their lack or imbalances may affect the success of the integrated approach. Language experts who assume the leading or expert role in collaborative processes may be perceived as too dominant and undermining the disciplinary expertise of content lecturers (Jacobs, 2007; Weinberg \& Symon, 2017). Moreover, if language specialists work with a variety of subjects, they may engage in disciplinary concepts only superficially (Leibowitz et al., 2011). To avoid misgivings in CLIL environments, the roles of the two partners need to be clearly specified and the contextual and disciplinary differences of the concept of CLIL also to be considered, without underestimating the expertise of the other party. The new position of English in higher education creates new circumstances for ESP teachers: "they may need to reconsider their role as one of a 'guide on the side', 
able to cross disciplinary boundaries in collaboration with content teachers to orient and formulate learning outcomes and assessment protocols" (Taillefer, 2013: 7). Working with content specialists to increase their language awareness can give more visibility to language specialists and expand the range of their traditional tasks and roles such as teacher, course designer, material provider, researcher, collaborator, and evaluator (Dudley-Evans \& St John, 1998). In recognition of this change in the status and role of ESP specialists, Zhang (2016: 161) posits that "they [language specialist teachers] are well positioned to contribute to the identification of the language features to teach and the approach to teaching them", which places ESP teachers in a more central role in the transformation of students and their growth as future professionals.

\section{INSTITUTIONAL CONTEXT}

This paper considers the case of Universidad San Jorge (USJ), a private university located in Spain. The university has predominantly Spanish-speaking students and staff, except for the Physiotherapy Degree, where approximately half of the students are French. The number of Erasmus students is growing constantly and accounts for about five percent of the students as of the academic year 2016-2017. The English language was integrated into its official curricula in two ways. First, language-led ESP courses designed specifically for each degree programme are obligatory subjects in the initial years of almost all degree programmes. The 6-12 credit obligatory ESP subjects are designed specifically for each undergraduate degree programme around three types of competences: general, specific to the degree programme, and linguistic (specific competences of the subject). General linguistic competences were based on the CEFR B1 level for first year and B2 for second year students and are later further specified for each degree programme by the lecturers involved. However, groups may be heterogeneous as there is no entry requirement for students. Second, the institution-wide CLIL programme establishes that selected credits in content subjects are delivered through English. In this way, students are increasingly exposed to English throughout the degree programme leading to some subjects being taught entirely through English in the final years. Outside of the official curriculum, the university also offers extracurricular optional courses in general English at different levels as additional support for both students and staff.

The CLIL programme was developed and supervised by the Institute of Modern Languages whose lecturers, apart from teaching ESP courses in degree programmes, provide guidance and support for CLIL lecturers through courses, workshops as well as individual content-language support. These measures were developed to address content teachers' needs and concerns in terms of language and even more importantly, of the methodology of teaching through a foreign language and teaching methodology in general. More personalised support in the 
form of CLIL sessions offered by an assigned language specialist is available to all content lecturers, irrespective of their level of English or experience. The latest official term used in reference to the English lecturers involved in this work with content lecturers is CLIL tutor, so I will use this term for the purpose of this paper. As a rule, CLIL tutors work with a group of lecturers from one assigned degree programme and also teach the ESP course in the same programme. In such cases, they participate in the degree programme in two roles: as ESP teacher for students and CLIL tutor for content lecturers (CLIL lecturers). The original CLIL programme has undergone several modifications and adaptations. For example, it now includes two levels of CLIL training and accreditation processes for CLIL lecturers. Additionally, the Faculty of Communication has developed its own project called PACE (Program of Advanced Communication in English) which offers subjects entirely in English and is primarily aimed at international students. ESP lecturers/CLIL tutors still play an active role in the integration of English in content subjects, even though their role is changing as the process is evolving and content lecturers are becoming, at least in theory, more independent. Despite a considerable amount of attention and effort regarding content subjects and their teachers, the evolution and implications for the language and ESP component of the programme have been given less consideration. Rather than aiming at generalizations, this case study was conducted with a view to contributing new insights into the place of ESP teaching in a CLIL setting and its contribution to the development of disciplinary literacies.

\section{PARTICIPANTS AND METHODS}

Situated in the interpretive paradigm, this study seeks to gain insights into lecturers' perceptions of their experience as ESP lecturers and CLIL tutors in the context of the USJ from a phenomenological perspective (Ormston, Spencer, Barnard, \& Snape, 2014; Seidman, 2013). It reports on primarily qualitative data obtained from three sources: two open-ended questionnaires with six ESP lecturers/CLIL tutors including the author, interviews with four of them, and the study guides of their ESP courses. The data were collected over four academic years (2013-2017). The participants were all female academics with languageliterature-humanities backgrounds. Three of them are native speakers of English and the research was conducted in this language. For the lecturers selected for the interviews, ESP is their main academic teaching activity. It was assumed that the diversity of domains of their ESP courses would increase their ability to ascertain the nature of the impact that the CLIL programme has on their teaching. ESP subjects with many groups of students and various teachers have a subject coordinator, though all lecturers involved are equally responsible for the design and development of the subject. 
The research started with two online open-ended questionnaires to uncover respondents' general opinions about their work with content teachers as CLIL tutors and their role in it. The first part of each questionnaire dealt with personal information such as degree programmes, years of experience, and number of content teachers they had worked with. The second part included open-ended questions to reveal their perceptions of their experience as CLIL tutors and its impact on their work (Appendix 1). The last part of the second questionnaire, one year later, included questions based on the responses to the first questionnaire. Both questionnaires were completed by the same respondents online, who could write as much or as little as they wished (Appendix 2).

As written questions and responses cannot provide the same depth as a semistructured interview, the second part of this research was based on face-to-face interviews so that the researcher had the opportunity to deepen the discussion with the participants. The interviews aimed to explore the participants' own experiences and interpretations of their situation as ESP lecturers/CLIL tutors. As is characteristic of semi-structured interviews, open-ended guiding questions that covered a variety of topics had been prepared (Appendix 3), but the researcher was flexible and "open to following the leads of informants and probing into areas that arise during interview interactions" (Hatch, 2002: 94). The interviewer was a member of the group under investigation, so the interviews resembled a conversation between work colleagues. The researcher transcribed the interviews verbatim and then analysed, coded, and interpreted the data within interpretive framework (Hatch, 2002). The mixing of the methodologies and sources of information at different points in time also served as a form of data triangulation (Denzin, 1978) and helped to develop a fuller picture of the situation. In order to ensure the anonymity of the respondents, their personal details have been omitted, so the sources indicated in the excerpts cited in the following sections will refer to questionnaires (Q1/participants 1-6, Q2/participants 1-6) and four interviews (I/participants A-D).

The respondents currently work as CLIL tutors in the following undergraduate programmes: Physiotherapy, Architecture, Nursing, Pharmacy, Physical Activity and Sport, Journalism, Business Administration, Audiovisual Communication, and Advertising and Public Relations. The number of content lecturers assigned to each CLIL tutor ranged between 6 and 18 and depended on the number of teachers integrating English in each degree programme and usually varied slightly each year. The participants in the interviews normally teach more than one ESP subject in the following degree programmes: Physiotherapy, Law, Architecture, Nursing, Business Administration, Education, and Media. The last subject is currently offered jointly to students of several degree programmes in the Faculty of Communication but previously was delivered separately for each degree programme (Journalism, Audiovisual Communication, Advertising and Public Relations). 


\section{RESULTS AND DISCUSSION}

In the context under investigation, the participants played two concurrent roles as both ESP lectures for students and CLIL tutors for content lecturers. The analysis of the data identified three major themes which represent the main aspects of their work and illustrate the nature of their contribution to the degree programme: a) content-language support; b) ESP teachers in CLIL; and c) disciplinary communication within the subjects.

\subsection{Content-language support}

Specialising in language teaching, ESP practitioners are responsible for analysing students' specific needs and applying the necessary tools, frameworks, and principles to design an effective course for teaching the language, skills, and genres relevant to students' activities (Basturkmen, 2010; Paltridge \& Starfield, 2013). In light of the growing amount of English integrated in the content subjects, students' immediate needs are primarily linked to the content subjects taught through English and not so much with their future professional activities. The participants highlighted that although their courses are mainly language-focused and aimed at developing communicative skills within a given discipline, language and content are inescapably entwined. The content knowledge is beyond their area of expertise, but the participants wanted to be in control of the carrier content involved in their ESP courses and feel responsible for the quality of it, especially considering that they could hardly count on their students as informants.

The thing is that they're first years so they're learning with you and I think it's important for us to say from the start we're not experts, we're language experts, we're not content experts. (I/B)

The work with disciplinary experts in CLIL was recognised as a great opportunity to learn about the disciplines and their discourses and practices. The CLIL tutors underlined the need to be open to learning about their assigned discipline and feeling like a student or apprentice again. In this respect, they recognised the benefits of working for many years with the same degree programme, which allowed them to gain deeper insights into the discipline and be more aware of their CLIL partners' and students' needs. Contact with content lecturers from diverse subject matter backgrounds also raised the language teachers' awareness of the complexity of the disciplines and the communicative practices associated with them. Although the content they deal with in CLIL work with content lecturers is not always directly useful for their ESP teaching, it is certainly thought-provoking and enriching, as illustrated in these comments about direct benefits for ESP: 
Having the opportunity to learn from each lecturer and understand the mindset of different academic discourses. (Q1/5)

If we didn't have that contact with content lectures through CLIL, we wouldn't know what it is that they really need to learn. [...] And it's not just focusing on the language; we need to have an awareness of the content, so it works both ways. They need to have an awareness of the language, we need to have an awareness of the content in order to teach it better and help the students learn. (I/C)

As the students' immediate communicative needs are mainly for their academic activities in other subjects, CLIL sessions with content lecturers also helped to find out how the ESP course can prepare students for these activities and ESP courses explicitly state this goal in their Study Guides, for example:

Your English classes are also designed to help you understand and participate more fully in other subjects that integrate credits in English. (Nursing)

In addition, this subject will help you to make the most of other content subjects where English is integrated. (Physiotherapy)

Given such close interconnections with content subjects, the participants pointed out that published ESP materials aimed at professional contexts were rarely applicable or needed substantial adjustments to their students' academic development and content knowledge covered in other subjects. Consultations with subject specialists proved to be invaluable when deciding on the carrier content of the courses, looking for synergies between the subjects and identifying reliable materials to be used, especially in areas where ESP teachers did not have any academic background, for example, in physiotherapy (Bruton \& Woźniak, 2013).

Integrating English in content subjects creates additional requirements for the design of ESP courses as the real content and carrier content become more diffuse and require constant adaptations and updates, which leads to constant 'work in progress'. All in all, support between ESP and CLIL subjects went both ways, which confirms that finding clear-cut divisions between ESP and CLIL is no longer possible:

It's difficult to separate how far in your ESP course are you helping them (content teachers) to do their CLIL better, who is helping who. I think it's a very complex relationship but it's one that certainly can't be ignored... (I/B)

Institutional attention concentrates on supporting content lecturers in the integration of English in their teaching, whereas the integration of content knowledge in parallel ESP courses is taken for granted. The participants with an academic background in a given field were able to combine language and content knowledge more confidently, as is the case of ESP lecturers in the education 
degree. Their own experience as teachers and academic training made them more comfortable in integrating specialised language and content knowledge. They also noted that their ESP courses actually involved content learning objectives. These participants perceived it a good way to prepare their students for their future professional practice, but the dividing line between content and language teaching becomes even more blurred and inspires concerns about the status of ESP subjects. According to institutional policy, ESP courses, as taught in English by default, cannot count on additional support, which suggests that the university considers only the language of instruction and not the true integration of content and language towards the development of disciplinary literacies. Consequently, there is a feeling that ESP lecturers' efforts towards the coherent integration of adequate content knowledge are not fully recognised. This is particularly important for those participants who teach ESP courses in a range of very different domains:

There is a kind of a fine line between content and language as well and sometimes we're teaching that kind of content as well, [...] so you have to build up your knowledge in those subjects in order to know what type of English to teach, or what other language needs they have. I guess maybe that's not understood, it's just we're English teachers and we have to teach language but what language? How? (I/D)

We need to be more flexible than other lecturers who always work within the same faculty, we need to adapt to new situations rapidly. The design of each ESP course requires a lot of research into the discipline, genres and communicative needs. (I/A)

\subsection{ESP teachers in CLIL}

The work of ESP teachers as CLIL tutors was undertaken to support content lecturers to effectively integrate English into their subjects. One-to-one sessions with CLIL lecturers were dedicated to activities ranging from helping to select the content suitable for teaching through a foreign language, deciding together on the strategies to be used, helping to design the materials, identifying linguistic and cognitive difficulties of the activities, to establishing assessment criteria and occasional team-teaching. Further, observing the jointly prepared classes to see the direct impact of the preparation on the actual class interaction in English delineated the lines of the follow up and motivated CLIL tutors. Almost all CLIL tutors had already taken part in occasional team-teaching activities, but collaborative activities in the classroom mainly included evaluating students' presentations and giving feedback on their oral communication skills and use of English, assisting less confident teachers in the classroom, helping to moderate a debate session in English, or taking part in a simulation or role-play, for example, as a fictitious patient. The results show that the work of CLIL tutors concentrated on supporting lecturers and involved only occasional direct support for students. 
Despite some challenges, misconceptions or even occasional tensions with content lecturers, witnessing content lecturers' growing confidence in using English in class and contributing to their professional development as university teachers was a source of CLIL tutors' great professional and personal satisfaction. For the CLIL tutors, who have a background in language, literature or humanities, this cross-disciplinary initiative proved to be a demanding yet rewarding experience and a great opportunity to expand their professional horizons beyond teaching language-led courses. They highlighted positive aspects of this experience, although they also recognised that some of their partners did not assign a high priority to this work, be it due to time constraints, self-reliance, or lack of awareness of the need to deal with language issues.

The findings show that methodology issues needed to be addressed in the first place despite visible improvements in this area thanks to the compulsory CLIL training course for novice CLIL teachers. Both the questionnaires and the interviews confirmed that the main and most urgent role for CLIL tutors was that of a methodology guide, especially in terms of challenging content teachers' misconceptions on how to deliver classes beyond a lecture format and opening them towards the idea that introducing a foreign language in their teaching goes beyond just changing the language of instruction as a "vehicle of communication" (Cots, 2013: 117). The CLIL tutors generally acknowledged that the most challenging part of this work was to raise content lecturers' awareness that being an expert in their discipline is not enough to teach it effectively, for example, "to get some lecturers to think 'outside the box', to get lecturers to really reflect on how they teach" (Q2/5).

Although being a methodology guide is the most common response in questionnaires and interviews, in practice the CLIL tutors performed several roles in combination, which at times are difficult to specify and require clarification. From the responses in the first questionnaire, the following roles of CLIL tutors emerged (in alphabetical order): assistant, coordinator, interdisciplinary mediator, language consultant, methodology guide, student/apprentice, supervisor, team member, or even translator. The second most common role was that of a language consultant, but this role was subject to different interpretations, including its total rejection:

With teachers who think I am a translator or a language consultant, I rectify their impression as soon as we start working together very explicitly. $(\mathrm{Q} 2 / 3)$

Some CLIL tutors noted that dedicating time to repetitive and less 'stimulating' activities such as rehearsal sessions for less confident teachers, practising pronunciation or correcting their written materials may lead to certain loss of motivation. Others, however, highlighted their role in making language and its role in the discipline visible to content lecturers (Lillis \& Scott, 2007), as illustrated in the following extracts from interviewee I/C: 
I'm a language consultant in terms of making them language aware [...], from the words, to the sentence level, [...] to the genres of the discipline.

[...] but that is done through language, so it's connected with language awareness and it's connected with the discourse of the discipline, which can be very different, [...], between health sciences, between communication, architecture, the way they see their subject and the way they express it, so they can be quite different.

\subsection{Disciplinary communication within the subjects}

Although our involvement in the ESP courses may seem skills-oriented, and is viewed as such by the university policies, the participants also aimed at introducing disciplinary practices for which certain content knowledge is required. In line with Yang's (2016) findings, the ESP teachers accepted the connection between their language-led subject and the disciplinary content studied in CLIL subjects, so consultations with content specialists were sought and appreciated. Nonetheless, although the participants agreed to consider the necessities put forward by their CLIL colleagues to complete specific tasks in English, they were concerned about limiting their subject to a remedial function, which brings us back to the issue of the status of the ESP subject. Some of them underlined that as specialists in language teaching, they aimed to equip students with skills necessary to communicate, study, and work effectively on an international scale as 'disciplinary literate graduates' (Airey, 2011), and not only to help content lecturers to achieve their teaching aims. One participant underscored that content lecturers' requests sometimes had little relevance to real communicative practices within the discipline in question and did not deserve much attention in the ESP course, so the ESP lecturer should have the freedom to address them or not.

The institutional focus on content teachers also raises concerns about the professional development of ESP lecturers/CLIL tutors and their place in the institutional policies which seem to concentrate on supporting content lecturers towards being able to teach through English independently. Generally, the more knowledgeable the participants were in the discourse of the discipline and experienced as CLIL tutors, the greater their willingness to contribute more fully to the development of students' disciplinary literacies not only in language-led courses but also in content subjects through embedding activities to promote more 'transformative' approaches to disciplinary communication not only in English but also in Spanish. For many CLIL tutors, stronger professional and personal ties with other faculties and the assigned degree programme added to their sense of being part of the team who shape the degree programme and its goals, as opposed to merely playing a secondary role as experienced by teachers of disciplinary language in many tertiary level environments (Airey, 2016). However, the treatment that each CLIL tutor received was at the discretion of each degree 
programme and their experiences were not always so positive. Some of the CLIL tutors also underlined that sometimes they felt like 'visitors', 'invisible' help or even 'second class teachers'. They were open to accept the fluidity of their role and recognised the need to adapt, and yet they were not ready to accept their role as only "a guide on the side" (Taillefer, 2013: 7). Although teaching methodology and language support were still the main issue CLIL tutors dealt with in their work with content lecturers, they wanted to engage in more advanced tasks related to the discipline and further contribute to the development of content teachers and students, for example:

I feel I can contribute towards helping content lecturers become more effective lecturers which will benefit learners. (Q2/5)

Almost all CLIL tutors were involved in assessment and evaluation undertakings in content subjects, though not necessarily in the classroom, and for the time being, to a rather limited extent. Their support in this area primarily consisted of helping content lecturers to prepare assessment rubrics that content teachers could later use independently. The extract below about a team-teaching project indicates that CLIL tutors want to go beyond just helping to integrate English in the disciplinary content but also want to be an effective help in their students' learning process through reflection on important issues within the field and be part of their development as future professionals:

It is very enriching, it's very good, I certainly learnt a lot and when you're preparing the activity, when you're focusing ..., you're thinking about the language, you're thinking about the content, you're looking for the right resources that would impact the students and get them thinking. (I/C)

As the next step in the evolution of the CLIL programme, joint activities in content subjects have been suggested, and have already been initiated, through teaching innovation and research projects on disciplinary communication. This would require a re-examination of the roles of language specialists in the programme as well as the commitment of content lecturers in the programme to work more closely with their ESP colleagues.

\section{CONCLUSION}

The aim of this study was to gain insights into ESP lecturers' perspectives of their double role in a CLIL university setting as both teachers of ESP courses and CLIL tutors for content lecturers. The collaborative links described in this paper were started to address content lecturers' needs whereas direct support for students was less frequent. In their work with content lecturers, ESP lecturers/CLIL tutors 
still concentrate on pedagogical and methodological issues to integrate L2 learning and raise content lecturers' awareness of the role of language in their disciplines and help them to address it in their teaching. Although time consuming, connections with the disciplines proved to be a rewarding experience for ESP lecturers/CLIL tutors, but given the increasingly blurred dividing line between content and language learning, further developments of the CLIL programme also need to reconsider the needs of ESP teachers. The findings are in agreement with previous studies showing that although the tasks of the development of disciplinary literacies is increasingly taken by content lecturers, it is ESP settings where disciplinary language skills are treated explicitly and properly assessed (Airey, 2016; González Ardeo, 2013; Yang, 2016). Whereas language-oriented ESP courses at the initial stage of university studies can offer a 'normative' approach to disciplinary literacies, they can prepare students for more 'transformative' activities in the following years in content subjects in which ESP lecturers, as CLIL tutors, can actively participate. To this end, the work between content and ESP teachers should be directed towards new opportunities for deeper integration of content and language and include learning outcomes for disciplinary literacies at different stages of university studies to complement each other and pave the way towards the different levels of disciplinary literacies required of their students. To link content and language learning goals effectively, endeavours to integrate content and language at university level require not only curiosity and engagement across disciplines, but first and foremost, a long-term institutional commitment with clear guidelines for both the ESP lecturers and content lecturers involved as well as a readiness for constant adjustments and 'work in progress'.

[Paper submitted 1 Jun 2017]

[Revised version received 21 Sep 2017]

[Revised version accepted for publication 28 Sep 2017]

\section{References}

Aguilar, M., \& Rodríguez, R. (2012). Lecturer and student perceptions on CLIL at a Spanish university. International Journal of Bilingual Education and Bilingualism, 15(2), 183197.

Airey, J. (2011). The disciplinary literacy discussion matrix: A heuristic tool for initiating collaboration in higher education. Across the Disciplines, 8(3). Retrieved from http://wac.colostate.edu/atd/clil/airey.cfm

Airey, J. (2016). EAP, EMI or CLIL? In K. Hyland, \& P. Shaw (Eds.), The Routledge handbook of English for academic purposes (pp. 71-83). Abingdon: Routledge.

Airey, J., Lauridsen, K. M., Räsänen, A., Salö, L., \& Schwach, V. (2017). The expansion of English-medium instruction in the Nordic countries: Can top-down university language policies encourage bottom-up disciplinary literacy goals? Higher Education, 73, 561-576. 
Arnó-Macià, E., \& Mancho-Barés, G. (2015). The role of content and language in content and language integrated learning (CLIL) at university: Challenges and implications for ESP. English for Specific Purposes, 37, 63-73.

Basturkmen, H. (2010). Developing courses in English for specific purposes. Basingstoke: Palgrave Macmillan.

Bernstein, B. (1999). Vertical and horizontal discourse: An essay. British Journal of Sociology Education, 20(2), 157-173.

Bruton, L., \& Woźniak, M. (2013). English for physiotherapy, physiotherapy for English: A synergistic approach. Revista Nebrija de Lingüística Aplicada, 13(Número especialActas de Congreso), 189-199.

Cots, J. M. (2013). Introducing English-medium instruction at the University of Lleida, Spain: Intervention, beliefs and practices. In A. Doiz, D. Lasagabaster, \& J. M. Sierra (Eds.), English-medium instruction at universities: Global challenges (pp. 106-127). Bristol: Multilingual Matters.

Coyle, D., Hood, P., \& Marsh, D. (2010). CLIL: Content and language integrated learning. Cambridge, UK: Cambridge University Press.

Dafouz, E., Hüttner, J., \& Smit, U. (2016). University teachers' beliefs of language and content integration in English-medium education in multilingual university settings. In T. Nikula, E. Dafouz, P. Moore, \& U. Smit (Eds.), Conceptualising integration in CLIL and multilingual education (pp. 123-143). Bristol: Multilingual Matters.

Dearden, J. (2014). English as a medium of instruction: A growing global phenomenon. London: British Council.

Denzin, N. K. (1978). Sociological methods. New York: McGraw-Hill.

Dudley-Evans, T., \& St John, M. J. (1998). Developments in English for specific purposes. Cambridge: Cambridge University Press.

Fortanet-Gómez, I. (2013). CLIL in higher education: Towards a multilingual language policy. Clevendon: Multilingual Matters.

González Ardeo, J. M. (2013). (In)compatibility of CLIL and ESP courses at university. Language Value, 5(1), 24-47.

Hatch, J. A. (2002). Doing qualitative research in educational settings. Albany: State University of New York Press.

Hyland, K. (2004). Disciplinary discourses: Social interactions in academic writing. Ann Arbor: University of Michigan Press.

Jacobs, C. (2005). On being an insider on the outside: New spaces for integrating academic literacies. Teaching in Higher Education, 10(4), 475-487.

Jacobs, C. (2007). Towards a critical understanding of the teaching of discipline-specific academic literacies: Making the tacit explicit. Journal of Educational Psychology, 41, 59-82.

Kuteeva, M., \& Airey, J. (2014). Disciplinary differences in the use of English in higher education: Reflections on recent language policy developments. Higher Education, 67(5), 533-549.

Lea, M. R., \& Street, B. V. (1998). Student writing in higher education: An academic literacies approach. Studies in Higher Education, 23(2), 157-172.

Lea, M. R., \& Street, B. V. (2006). The "academic literacies" model: Theory and applications. Theory into Practice, 45(4), 368-377. 
Leibowitz, B., Bozalek, V., Carolissen, R., Nicholls, L., Rohleder, P., Smolders, T., \& Swartz, L. (2011). Learning together: Lessons from a collaborative curriculum design project. Across the Disciplines, 8(3). Retrieved from https://wac.colostate.edu/atd/clil/leibowitzetal.cfm

Leonardi, V. (2015). Bridging the gap between ESP and CLIL in the university context. Iperstoria - Testi Letterature Linguaggi, 5 (Spring), 18-26.

Lillis, T., \& Scott, M. (2007). Defining academic literacies research: Issues of epistemology, ideology and strategy. Journal of Applied Linguistics, 4(1), 5-32.

Masuda, A. M. (2014). Exploring preservice teachers' emerging understandings of disciplinary literacy. Literacy Research and Instruction, 53(4), 326-346.

Ormston, R., Spencer, L., Barnard, M., \& Snape, D. (2014). The foundations of qualitative research. In J. Ritchie, J. Lewis, C. McNaughton Nicholls, \& R. Ormston (Eds.), Qualitative research practice: A guide for social science students and researchers (2nd ed.) (pp. 1-23). London: SAGE Publications Ltd.

Paltridge B., \& Starfield, S. (2013). Introduction. In B. Paltridge, \& S. Starfield (Eds.), The handbook of English for specific purposes (pp. 1-4). London: Wiley Blackwell.

Räisänen, C., \& Fortanet-Gómez, I. (2008). The state of ESP teaching and learning in Western European higher education after Bologna. In I. Fortanet-Gómez, \& C. Räisänen (Eds.), ESP in European higher education (pp. 11-51). Amsterdam: John Benjamins.

Seidman, I. (2013). Interviewing as qualitative research: A guide for researchers in education and the social sciences (4th ed.). New York, NY: Teachers College Press.

Shanahan, T., \& Shanahan, C. (2008). Teaching disciplinary literacy to adolescents: Rethinking content-area literacy. Harvard Educational Review, 78(1), 40-59.

Skinnari, K., \& Bovellan, E. (2016). CLIL teachers' beliefs about integration and about their professional roles: Perspectives from a European context. In T. Nikula, E. Dafouz, P. Moore, \& U. Smit (Eds.), Conceptualising integration in CLIL and multilingual education (pp. 145-167). Bristol: Multilingual Matters.

Taillefer, G. (2013). CLIL in higher education: The (perfect?) crossroads of ESP and didactic reflection. Asp (Online), 63, 31-53.

Tarnopolsky, O. (2013). Content-based instruction, CLIL, and immersion in teaching ESP at tertiary schools in non-English-speaking countries. Journal of ELT and Applied Linguistics (JELTAL), 1(1), 1-11.

Thesen, L., \& van Pletzen, E. (Eds.) (2006). Academic literacy and the languages of change. London: Continuum.

Tudor, I. (2008). The higher education challenge for higher education institutions in Europe, and the specific case of CLIL. In J. Martí i Castell, \& J. M. Mestres i Serra (Eds.), El Multilingüisme a les universitats en l'espai europeu d'educació superior [Multilingualism in universities in the European higher education area] (pp. 41-64). Barcelona: Institut d'Estudis Catalans.

Weinberg, L., \& Symon, M. (2017). Crossing borders: The challenges and benefits of a collaborative approach to course development involving content and language specialists in different countries. In J. Valcke, \& R. Wilkinson (Eds.), Integrating content and language in higher education: Perspectives on professional practice (pp. 135-150). Frankfurt am Main: Peter Lang.

Wingate, U. (2015). Academic literacy and student diversity: The case for inclusive practice. Bristol, Buffalo: Multilingual Matters. 
Wingate, U., \& Tribble, C. (2012). The best of both worlds? Towards an English for academic purposes/academic literacies writing pedagogy. Studies in Higher Education, 37(4), 481-495.

Woodward-Kron, R. (2008). More than just jargon - the nature and roles of specialist knowledge in learning disciplinary knowledge. Journal of English for Academic Purposes, 7, 234-249.

Yang, W. (2016). ESP vs. CLIL: A coin of two sides or a continuum of two extremes? ESP Today, 4(1), 43-68.

Zhang, Z. C. (2016). "Somewhere in the middle is the optimal balance": A subject specialist negotiating business and language in teaching business writing. ESP Today, 4(2), 145-164. https://doi.org/10.18485/esptoday.2016.4.2.1

MONIKA WOŹNIAK teaches English for Specific Purposes in Physiotherapy and Pharmacy degree programmes at San Jorge University in Spain. She graduated in English Philology from the University of Gdańsk and holds a European Doctorate from the University of Jaén. She also completed a Master in Intercultural Communication, Public Service Interpreting and Translation at the University of Alcalá. Her main research interests include phraseology and culture, lexicography, and integrating content and language in higher education.

\section{Appendix 1}

- Your native language

- How long have you been working with content teachers?

- Which faculty/faculties have you worked with?

- Which degree programme(s) have you worked with? You can write comments next to your degree programmes if you like.

- How many content lecturers do you work with?

- How would you describe your role in your work with content lecturers? How do you feel about this role?

- How do you divide your work with your content teachers (i.e. who does what exactly) and how do you feel about this division?

- What do you dedicate your time to? $1=$ highest, $3=$ lowest. Click on an item in the list on the left, starting with your highest ranking item, moving through to your lowest ranking item.

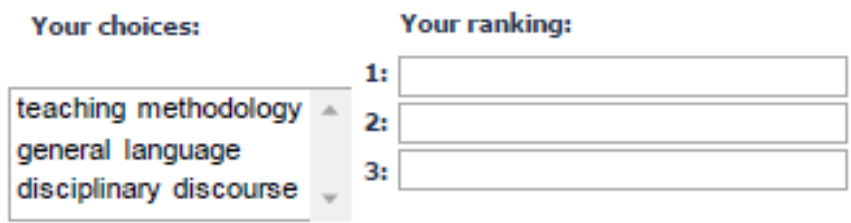

- Do you take part in the assessment/evaluation of CLIL activities? Describe your role.

- Have you done any team teaching? What was your role?

- Who initiates contact/asks for meetings? Describe your situation. 
- What are the most positive aspects of your work with content lecturers? If you work with various degrees programmes, please indicate the degree you refer to.

- What are the most difficult aspects of your work with content lecturers? If you work with various degree programmes, please indicate which degree you refer to.

- How do you think your work with content lecturers could be improved?

- What could be done from the ILM to improve your work with content teachers?

- What is your opinion about the system of credits you have for CLIL?

\section{Appendix 2}

- How would you define your actual role in your work with content teachers? (1= highest, 9= lowest). Click on an item in the list on the left, starting with your highest ranking item, moving through to your lowest ranking item.

Your choices:

Your ranking:

\begin{tabular}{|l|l|}
\hline methodology guide & 1: \\
team member & $2:$ \\
supervisor & $3:$ \\
assistant & $4:$ \\
interdisciplinary mediator & $5:$ \\
student/apprentice & $6:$ \\
language consultant & $7:$ \\
coordinator & $8:$ \\
translator & $9:$
\end{tabular}

- What role would you like to have in your work with content teachers? (1= highest, 9= lowest)

- Click on an item in the list on the left, starting with your highest ranking item, moving through to your lowest ranking item.

Your ranking:

1:

2:

3:

4:

$5:$

6:

7:

8:

9:

\section{Appendix 3}

- How would you describe your role in the work with your CLIL teachers? Select the most relevant for you: methodology guide, team member, supervisor, assistant, interdisciplinary mediator, student/apprentice, language consultant, coordinator, translator.

- Did you do any team-teaching? What was your role? How did you feel about that?

- Has your work with content teachers changed in the last years? How? 
- What do you dedicate your time to? Rate the following: general language, disciplinary discourse, teaching methodology.

- Did your work as CLIL tutor influence your ESP subject? How?

- How do you decide on the contents of your subject?

- What are the main objectives of your ESP subject? What disciplinary competences does it develop?

- How will the subject evolve in the future? Will the CLIL programme change it?

- How do you envisage your role in ESP and CLIL?

- Are there any topics you would like to mention that I haven't asked? 